\title{
Effects of traditional coppice practices and microsite conditions on tree health in a European beech forest at its southernmost range
}

\author{
Sebastiano Cullotta, Gaetano La \\ Placa, Federico G Maetzke
}

\begin{abstract}
European beech (Fagus sylvatica) grows at the southern limit of its range in the mountain-Mediterranean vegetation belt up to the timberline. The southernmost beech forests of Sicily (southern Italy) show peculiar ecological, structural and silvicultural characteristics, growing in fragmented and isolated stands near the timberline and in topographically marginal unfavorable habitats. Past silvicultural practices increased the heterogeneity of stand structure at these sites. We compared stand structural characteristics and tree health in coppice-cut and control beech stands with respect to the local topographic gradient (bottom, slope and ridge) and canopy cover (clearing/border vs. interior trees). Our results clearly showed a correlation between declining tree health (crown and bark damage, higher percentage of dead trees and lower seedling density) and recent coppice-cuts, poor (marginal) site quality (on ridges and slopes) and reduced canopy cover (in clearing/border trees). The decrease of tree health indicate an increasing threat to the long-term viability of beech stands facing multiple environmental stress factors (such as those related to southern latitude and topographic position). Declining tree health in the control plots also supports this hypothesis. We concluded that traditional forest management practices, such as coppice-cuts applied regardless to the specific microenvironmental conditions, may pose a risk to beech forest health at the southernmost edge of the species' range.
\end{abstract}

Keywords: Marginal Beech Sites, Site-specific Ecology, Topographic Gradient, Cover Fragmentation, Silviculture, Coppice-cuts, Tree Damage, Madonie Mts, Sicily

ces and specific adaptations (Magri et al. 2006, Rose et al. 2009).

Previous studies on climate change (Thomas et al. 2004, Gessler et al. 2007) suggested that the survival of beech stands is significantly threatened at the southernmost limits of the species' range (Berry et al. 2002, Attorre et al. 2008, Benito Garzon et al. 2008). Kramer et al. (2010) projected that both southern and northern limits of European beech will shift northward. In addition, climate change may deeply affect natural regeneration processes (Gessler et al. 2007, Silva et al. 2012), growth and productivity (Ciais et al. 2005, Dittmar et al. 2006, Jump et al. 2006, Seynave et al. 2008, Aertsen et al. 2014), and physiological performance (Erasmus et al. 2004, Ren- $\square$ Dipartimento SAF - Scienze Agrarie e Forestali, Università degli Studi di Palermo, Viale delle Scienze, Edificio 4, Ingresso H, 90128 Palermo (Italy)

@ Sebastiano Cullotta (sebastiano.cullotta@unipa.it)

Received: Feb 16, 2015 - Accepted: Nov 12, 2015

Citation: Cullotta S, La Placa G, Maetzke FG (2016). Effects of traditional coppice practices and microsite conditions on tree health in a European beech forest at its southernmost range. iForest 9: 673-681. - doi: 10.3832/ifor1603-008 [online 2016-03-12]

Communicated by: Renzo Motta nenberg et al. 2006, Granier et al. 2007).

In the Mediterranean region mean temperatures are currently increasing, rainy seasons are becoming shorter and drought periods are longer and more frequent; a shift upward of the treeline and a shrinkage of the species' distribution in southern Europe is anticipated (Peñuelas \& Boada 2003, Jump et al. 2006). The Sicilian beech stands growing on the northern coastal mountaintops are expected to experience increasingly severe drought and warming, leading to decline, population decreases and potential local extinction of the species (Piovesan et al. 2008, Pignatti 2011).

In recent years, severe drought has affected beech stands at the southern sites, which calls for an active management of stands. Past silvicultural practices have largely influenced stand structure variability of beech forests in all Mediterranean mountains, by creating and maintaining a wide spectrum of structural forms (Bengtsson et al. 2000). Coppicing to supply wood for charcoal in local markets has been the major factor affecting forest structure (Coppini \& Hermanin 2007, Ciancio et al. 2008, Nocentini 2009, Sabatini et al. 2015). With a decreasing demand for charcoal production, the majority of the beech coppices were no longer managed, and many are currently being converted to high forests (Bergmeier \& Dimopoulos 2001, Cian- 
Fig. 1 - (a) Distribution of Fagus sylvatica in Europe (after EUFORGEN project map); (b) beech forests in Sicily and (c) in the study area (Madonie mountains) Data from the Forest Map of Sicily Regional Forest Information System 2011). Sample sites are indicated by black circles in the panel (c).

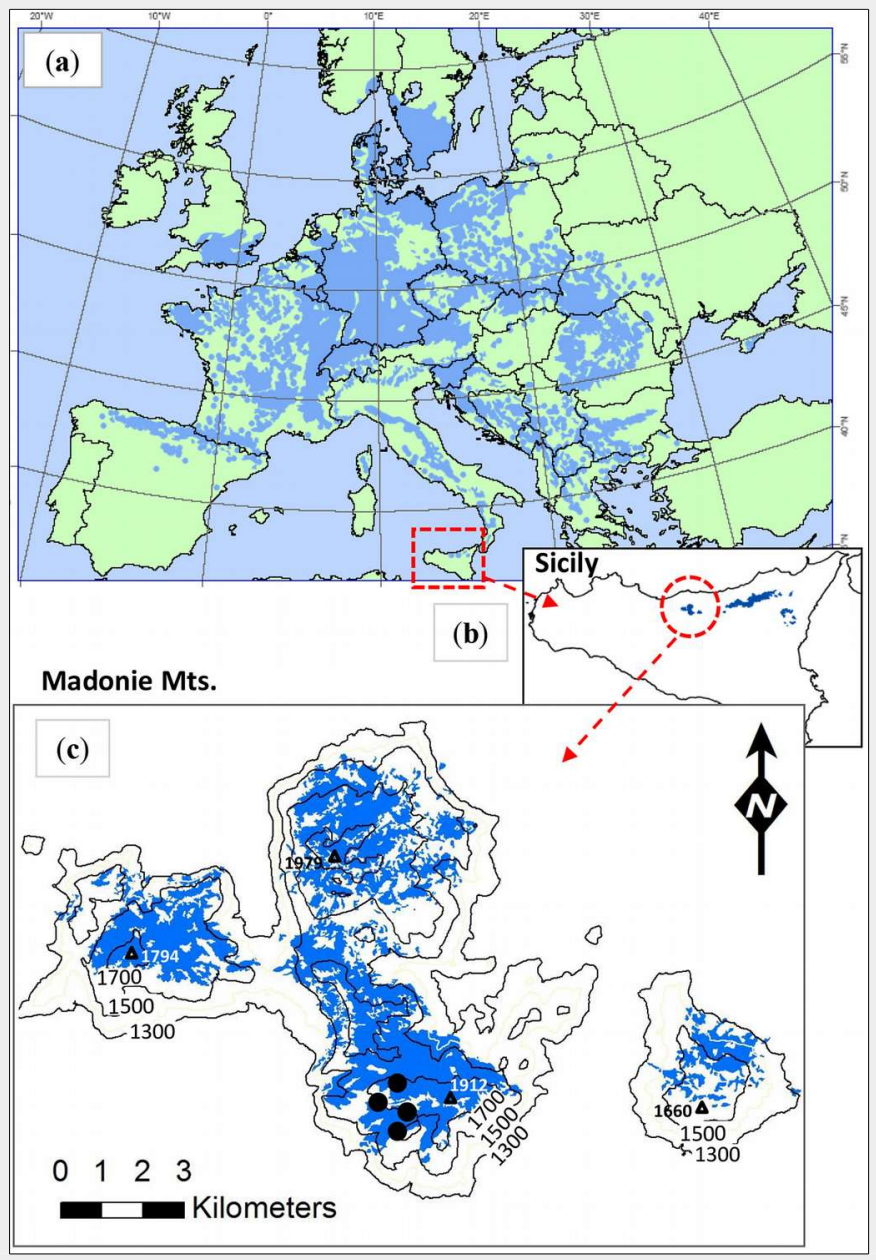

cio et al. 2006, Nocentini 2009, Lombardi et al. 2012).

At the forest stand level, climate and management practices may interact with topography, cover and edge effects. Indeed, Mediterranean mountain beech stands located on ridges or steep slopes, as well as those that are in fragmented stands or near edges, are negatively affected by the increased exposure to wind, turbulence, warmer air and higher soil temperatures (Harper et al. 2005, Heithecker \& Halpern 2007, Barbeta et al. 2011).

This study focuses on the structural characteristics of coppice beech stands growing on the Madonie Mountains (the northern mountain chain of Sicily) in relation to the local topographic gradient and the forest cover fragmentation, with the following goals: (i) to verify whether traditional coppice practices are still suitable for sustainable management of beech at its southernmost limit; (ii) to identify silvicultural practices for maintaining beech stands in these marginal areas. To evaluate the effect of coppicing on stand structure and tree health, structural characteristics, seed ling density, defoliation index, bark damage and the percentage of dead trees were compared between recently coppiced and non-cut (control) forest plots. ple stems and reduced height. Both deciduous and evergreen oaks (Quercus petraea,
Q. ilex, Q. pubescens) can be found in beech stands, mainly at lower elevations (1200$1300 \mathrm{~m}$ a.s.I.).

Traditionally, beech forests in Sicily were mostly managed as coppice for charcoal production (Hofmann 1960). All beech forests are still used for occasional grazing and wood harvesting, resulting in highly diversified structures which cannot be easily classified as standard structural managing models (simple coppice, coppice with standards or selection coppice). Wildfires are rare in the higher vegetation belt, including in beech forests.

\section{Data collection}

Six study sites (A, B, C, D, E and F) were selected in the upper part of the Madonie mountains after a review of the local literature on beech forests (Hofmann 1960, Camerano et al. 2011, Cullotta \& Marchetti 2007) based on the following criteria: (i) coppice stands must have been recently (last one or two decades) managed using local, traditional silvicultural methods; (ii) at least part of the stands must not have been managed in the last three or four decades (to be used as control plots).

A field survey was conducted at each site on 2 paired plots (i: recently coppiced; ii: control), totaling 12 sample plots (Fig. 2, Tab. 1). Each plot was circular, with a radius of $20 \mathrm{~m}$. Plots were located in pure beech stands along an elevation (1600-1800 m a.s.l.) and topographic gradient (bottom, slope, ridge - Fig. 3). Paired plots allowed the comparison of stand characteristics (structural variables, seedling density, tree defoliation index, bark damage, and the percentage of dead trees) between recently coppices stands and controls growing under similar ecological conditions (Fig. 2, Fig. 3). Altitude, topographic position, aspect and slope of each plot were recorded, and its center georeferenced by GPS. The position of all trees in the sample area was determined by polar coordinates (distance from plot center and azimuth). To determine the maximum age of shoots in each plot, core samples were collected from the base of the six largest stems in the plot using an increment borer.

Diameter at breast height (DBH) of all living trees (all shoots $>3 \mathrm{~cm}$ on each stool) and tree height $(\mathrm{H})$ were measured. Additionally, the following structural characteristics were recorded in each sample plot: height of crown insertion $(\mathrm{m})$, crown radius (mean of the radii taken at the four cardinal points), canopy cover (\%), stool number and location, coppice-shoot number per stool.

The presence and location of beech regeneration was determined by recording all plants with diameter (D) $<3 \mathrm{~cm}$ (at ground level) and height $(\mathrm{H})<1 \mathrm{~m}$ along two transects in each sample plot; the transects were $40 \times 2 \mathrm{~m}$, oriented according along the cardinal directions. Seedling production (seedlings $\mathrm{ha}^{-1}$ ) was determined by counting all recruitments of the current year 
Tab. 1 - Physiographic characteristics of the study sites. The label "cut" indicates recently coppice-cut plots, while control plots are labelled as "control". Geographic coordinates are given for the center of the two paired plots sampled at each site. Altitude, aspect, slope and stand density are given as the mean of the two plots.

\begin{tabular}{|c|c|c|c|c|c|c|c|}
\hline Site name & Label & $\begin{array}{l}\text { Latitude } \\
\text { Longitude }\end{array}$ & Topography & $\begin{array}{l}\text { Altitude } \\
\text { (m a.s.l.) }\end{array}$ & Aspect & $\begin{array}{c}\text { Slope } \\
\text { (\%) }\end{array}$ & $\begin{array}{l}\text { Stand density } \\
\left(\mathrm{n} \mathrm{ha}^{-1} \pm \mathrm{SE}\right)\end{array}$ \\
\hline Vallone Prato & $\mathrm{A}_{\text {(cut) }}$ & $\begin{array}{l}37^{\circ} 50^{\prime} 52^{\prime \prime} .77 \mathrm{~N} \\
14^{\circ} 02^{\prime} 14^{\prime \prime} .60 \mathrm{E}\end{array}$ & bottom & 1640 & SE & $30-40$ & $2769 \pm 280$ \\
\hline Piano lola & $\mathrm{B}_{\text {(control) }}$ & $\begin{array}{l}37^{\circ} 50^{\prime} 50^{\prime \prime} .14 \mathrm{~N} \\
14^{\circ} 02^{\prime} 10^{\prime \prime} .43 \mathrm{E}\end{array}$ & bottom & 1630 & $\mathrm{~S}$ & 1020 & $4687 \pm 368$ \\
\hline Piano lola-Piano Grande & $\mathrm{C}_{\text {(cut) }}$ & $\begin{array}{l}37^{\circ} 50^{\prime} 45^{\prime \prime} .54 \mathrm{~N} \\
14^{\circ} 02^{\prime} 07^{\prime \prime} .63 \mathrm{E}\end{array}$ & slope & 1720 & NO & $30-40$ & $2984 \pm 301$ \\
\hline Piano Grande & $D_{\text {(cut) }}$ & $\begin{array}{l}37^{\circ} 50^{\prime} 32^{\prime \prime} .59 \mathrm{~N} \\
14^{\circ} 02^{\prime} 06^{\prime \prime} .64 \mathrm{E}\end{array}$ & ridge & 1770 & - & $0-5$ & $3287 \pm 316$ \\
\hline Piano Grande & $\mathrm{E}_{\text {(control) }}$ & $\begin{array}{l}37^{\circ} 50^{\prime} 29^{\prime \prime} .08 \mathrm{~N} \\
14^{\circ} 02^{\prime} 14^{\prime \prime} .75 \mathrm{E}\end{array}$ & ridge & 1760 & - & $0-5$ & $14705 \pm 613$ \\
\hline Piano lola-Piano Grande & $\mathrm{F}_{\text {(control) }}$ & $\begin{array}{l}37^{\circ} 50^{\prime} 45^{\prime \prime} .43 \mathrm{~N} \\
14^{\circ} 01^{\prime} 58^{\prime \prime} .92 \mathrm{E}\end{array}$ & slope & 1700 & NO & $30-40$ & $5411 \pm 357$ \\
\hline
\end{tabular}

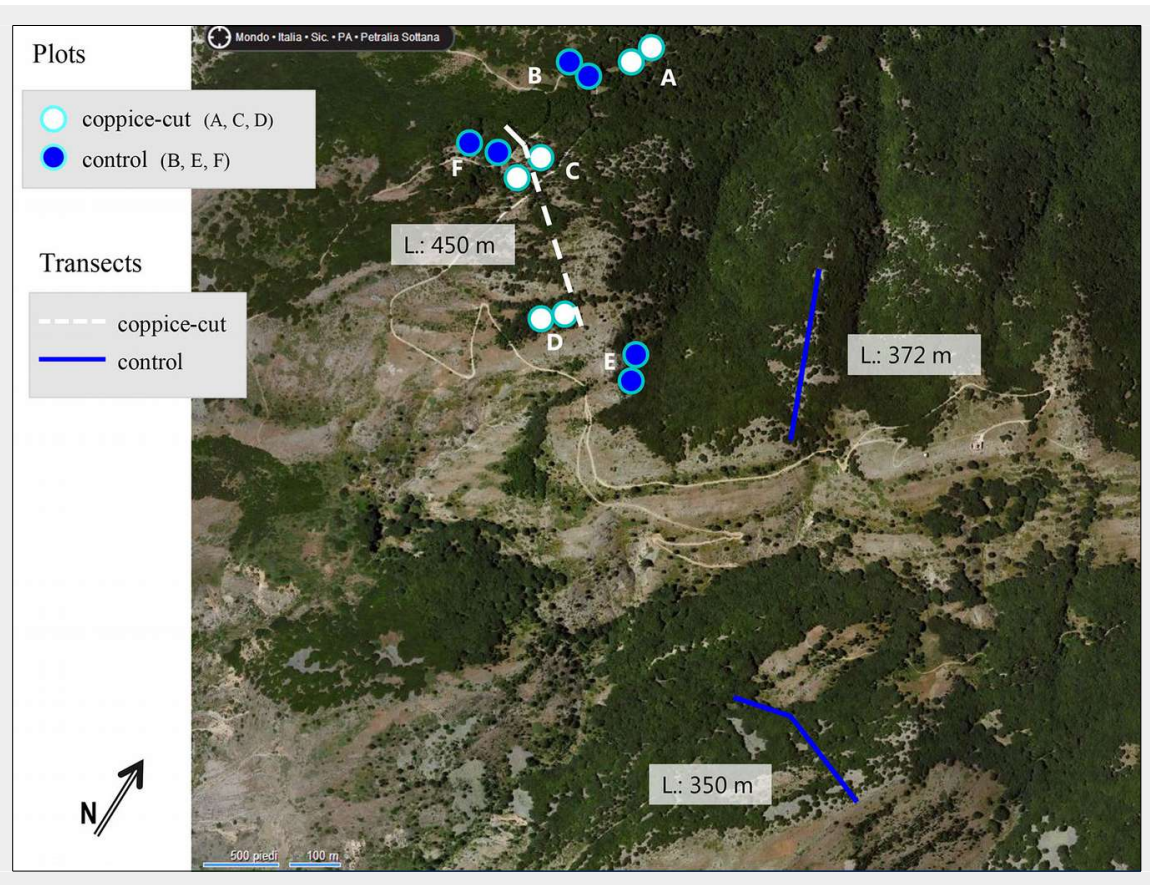

Fig. 2 - Location of the paired plots at each sample site (A, B, C, D, E, F) and location of the sample transects. ( $L$ ): length of each transect in meters.

along the transects, while recruitments of the previous years were classified as saplings (saplings ha ${ }^{-1}$ ). Seedling and sapling were defined according to Borghetti \& Giannini (2004), Papalexandris \& Milios (2010) and Barbeta et al. (2011).

Based on the above measurements, the following structural parameters were calculated for each sample plot: stem density (shoots ha ${ }^{-1}$ ) and stool density (stools ha ${ }^{-1}$ ); mean tree $\mathrm{DBH}(\mathrm{cm})$ and mean tree height $(\mathrm{m})$; basal area $\left(\mathrm{G}, \mathrm{m}^{2} \mathrm{ha}^{-1}\right)$; frequency distribution of trees with respect to DBH $(2.5 \mathrm{~cm}$ classes) and $\mathrm{H}$ ( $5 \mathrm{~m}$ classes). The number of individuals in each size class for DBH and $\mathrm{H}$ was calculated based on the stand density of each plot (number of individuals per hectare). The total basal area $\left(\mathrm{G}, \mathrm{m}^{2}\right)$ from all the shoots for each individual (stool) was also calculated. The whole shoot volume $\left(\mathrm{V}, \mathrm{m}^{3}\right)$ was obtained using the mathematical models developed by the Italian National Forest Inventory (MAF-ISAFA
1985) and the Sicilian Regional Forest inventory (Hofmann et al. 2011).

\section{Tree health data collection}

Damage was assessed for all beech trees in each sample plots. Crown defoliation and bark damage were estimated visually and defined as the percentage of crown leaf loss and the percentage of damaged stem bark (necrosis; cracks), respectively. Stem bark damage are to be considered as the effect of direct sunlight on the bark after the canopy opening by cutting. To assess crown damage, the shoot crown on each stool was split into $9(3 \times 3)$ quadrants (Fig. 4), and each quadrants assigned to a damage and defoliation class (based on $5 \%$ percentage of increment). Trees were observed systematically from the south side. Dead trees were recorded, and the ratio of dead to total individuals was calculated for each plot.

In addition to sampled plots, tree health

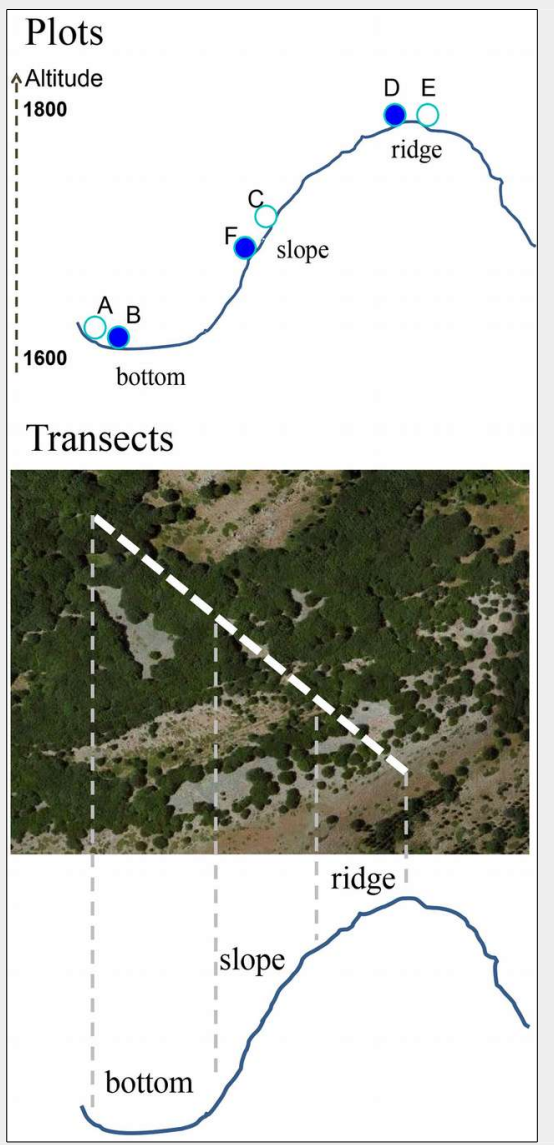

Fig. 3 - Location of the paired plots and the transects along the topographic and elevation gradients.

data collection was extended to a total of three transects located along the topographic and altitudinal gradient (Fig. 2, Fig. 3). Each transect was $5 \mathrm{~m}$ large and 350-450 m long, and included bottom, slope and ridge segments. The same procedure of damage assessment adopted for plots was also used for the transects.

\section{Data analysis}

The non-parametric Kolmogorov-Smirnov (KS) test was used to test for differences in the diameter distribution of stems or shoots (by size class) between coppice-cut 


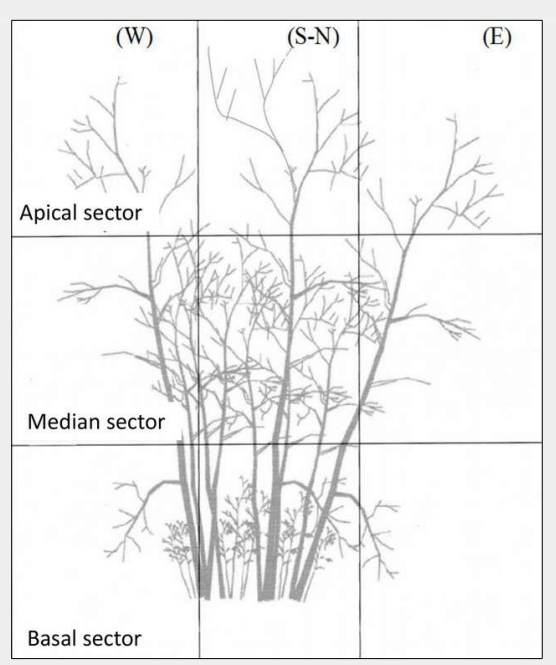

Fig. 4 - Schematic representation of the shoot crown on a stool, divided into 9 (3x3) quadrants in order to assess defoliation and stem damage in the different parts of the plant.

and control plots. The Student's t-test was applied to compare structural variables (plant and stool density, no. of shoots per stool, mean tree DBH, H, G and V), regeneration density (seedlings and saplings), and damaged and dead trees between coppiced and control plots.

Differences in the measured variables among silvicultural treatments (coppicecut plots vs. non-cut plots/controls), topography (bottom, slope and ridge plots), and canopy cover (clearing/edge trees vs. interior trees) were tested by ANOVA. Mean comparison was carried out using the Tukey's post-hoc test $(\alpha=0.05)$.

All statistical analyses were carried out using the software package STATISTICA ${ }^{\circledR}$ version 8 (StatSoft Inc., Tulsa, OK, USA).

\section{Results}

\section{Structural characteristics}

The analysis of core samples extracted from the larger stools in the sample plots revealed that all the studied stands have been subject to previous coppice cuts 43 and 54 years ago. Only a single stem (shoot) of age of 63 and one of age 76 years were recorded in plots $E$ and $D$, respectively.

A total of 4714 stems/shoots with DBH $>3$ $\mathrm{cm}$ were measured in the 12 sample plots. The mean values ( \pm SE) of all measured and derived stand variables are reported in Tab. 3, for both coppice-cut plots (A, C, D) and control plots (B, E, F- Tab. 2).

Beech stands in coppice-cut plots were significantly less dense than control plots $\left(3013 \pm 232\right.$ vs. $8268 \pm 2040 \mathrm{n} \mathrm{ha}^{-1}-$ Student's $t=-2.57 ; p<0.05 ; \mathrm{df}=10$ ); the number of shoots per stool was also significantly smaller $\left(5.3 \pm 0.23\right.$ vs. $6.6 \pm 0.48 \mathrm{n} \mathrm{ha}^{-1}$ in coppice-cut and control plots, respectively - Student's $t=-2.39 ; \mathrm{p}<0.05 ; \mathrm{df}=800-$ Fig. 5). Contrastingly, the stool density was similar in both stand types (Student's $t=$ $-1.81 ; p=0.09, d f=10$ ).

Coppice-cut stands had significantly lower values of both basal area (Student's $t=$ -6.18; $p<0.01 ; d f=10$ ) and volume (Student's $t=-5.63 ; p<0.001 ; d f=10-$ Fig. 5 ,
Tab. 3). The diameter distribution of coppice-cut and control stands showed a similar shape, but were significantly different (KS test, $p=0.029$ ). In general, the number of individuals (stems) decreased from smaller to larger size classes. Student's t-test applied to each diameter class revealed significant differences for the intermediate classes (DBH 10, 12, $14 \mathrm{~cm}$ - Fig. 6a). Similarly, the cumulative distribution of volume per individual (summing all the stems of each individual) was significantly different between coppice-cut and control plots (KS test, $p=0.001-$ Fig. $6 b$ ), with significant differences in the intermediate volume classes (V 20, 40, 60, 80).

\section{Regeneration}

The number of seedlings and saplings was not significantly different in coppicecut and control stands (Fig. 5). Significant differences in regeneration were found among topographic positions after ANOVA (Fig. 7). Pooling data from coppice-cut and control plots together, regeneration was significantly lower on ridges as compared with other topographic locations (seedlings: $p<0.01$; saplings: $p<0.05$ - Fig. 7a). The number of seedlings showed a decrease from the lower to the higher elevation plots, while the number of saplings increased with the topographic gradient. In coppice-cut stands (Fig. 7b), the lowest regeneration level occurred on the ridges $(\mathrm{p}<$ 0.01 ), while the number of saplings decreased in the opposite direction from ridges down to the bottomlands. Contrastingly, seedling number was the highest in plots located on slopes $(p<0.05)$.

Tab. 2 - Structural characteristics of the sample plots (mean values) before and after the cutting treatments. The percentage of variation of density, basal area $(\mathrm{G})$, and volume $(\mathrm{V})$ after the cutting is reported. $\left({ }^{*}\right)$ : include the natural mortality in control plots.

\begin{tabular}{|c|c|c|c|c|c|c|c|c|c|c|}
\hline \multirow{2}{*}{ Plot } & \multirow{2}{*}{ Year of cut } & \multicolumn{3}{|c|}{ Density $\left(\mathrm{n} \mathrm{ha}^{-1}\right)$} & \multicolumn{2}{|c|}{$G\left(m^{2} h a^{-1}\right)$} & \multicolumn{3}{|c|}{$V\left(m^{3} h a^{-1}\right)$} & \multirow[b]{2}{*}{$\%$} \\
\hline & & Before & After* & $\%$ & Before & After* & $\%$ & Before & After* & \\
\hline $\mathrm{A}_{\text {(cut) }}$ & 2011 & 6891 & 4122 & 60 & 30 & 7 & 22 & 121 & 21 & 17 \\
\hline $\mathrm{B}_{\text {(control) }}$ & 2000 & 4862 & 175 & 4 & 32 & 1 & 2 & 136 & 3 & 2 \\
\hline$C_{\text {(cut) }}$ & 1997 & 5507 & 2523 & 46 & 18 & 8 & 42 & 57 & 24 & 42 \\
\hline$F_{\text {(control) }}$ & > 30 years ago & 5634 & 223 & 4 & 37 & 1 & 2 & 166 & 2 & 1 \\
\hline$D_{\text {(cut) }}$ & 1998 & 9868 & 6525 & 66 & 25 & 11 & 43 & 53 & 20 & 37 \\
\hline $\mathrm{E}_{\text {(control) }}$ & $>30$ years ago & 15308 & 603 & 4 & 49 & 1 & 2 & 149 & 3 & 2 \\
\hline
\end{tabular}

Tab. 3 - Stand parameter values after cut (mean \pm SE) for each sample site (two plots of each site).

\begin{tabular}{|c|c|c|c|c|c|c|}
\hline \multirow{2}{*}{ Parameter } & \multicolumn{6}{|c|}{ Site (mean \pm SE) } \\
\hline & $\mathbf{A}_{\text {(cut) }}$ & $\mathbf{B}_{\text {(control) }}$ & $\mathrm{C}_{\text {(cut) }}$ & $D_{\text {(cut) }}$ & $\mathrm{E}_{\text {(control) }}$ & $F_{\text {(control) }}$ \\
\hline Stand density $\left(\mathrm{n} \mathrm{ha}^{-1}\right)$ & $2769 \pm 280$ & $4687 \pm 368$ & $2984 \pm 301$ & $3287 \pm 316$ & $14705 \pm 613$ & $5411 \pm 357$ \\
\hline Stool density ( $\mathrm{n} \mathrm{ha}^{-1}$ ) & $637 \pm 37$ & $1098 \pm 59$ & $851 \pm 57$ & $461 \pm 41$ & $509 \pm 29$ & $1146 \pm 63$ \\
\hline N.shoots/stool & $4 \pm 0.26$ & $4 \pm 0.22$ & $3 \pm 0.27$ & $7 \pm 0.71$ & $29 \pm 3.23$ & $5 \pm 0.46$ \\
\hline $\mathrm{DBH}(\mathrm{cm})$ & 10.3 & 9.2 & 6.7 & 7.8 & 6.5 & 9.2 \\
\hline $\mathrm{H}(\mathrm{m})$ & 9.3 & 9.5 & 6.7 & 5.5 & 6.3 & 9.2 \\
\hline$G\left(m^{2} h a^{-1}\right)$ & 23.1 & 31.4 & 10.5 & 15.8 & 48.4 & 36.3 \\
\hline Seedlings density $\left(\mathrm{n} \mathrm{ha}{ }^{-1}\right)$ & $637 \pm 226$ & $485 \pm 174$ & $573 \pm 278$ & $294 \pm 154$ & $350 \pm 88$ & $605 \pm 112$ \\
\hline Saplings density $\left(\mathrm{n} \mathrm{ha}^{-1}\right)$ & $31.8 \pm 12.8$ & $31.8 \pm 11.4$ & $15.9 \pm 10.9$ & $23.9 \pm 12.8$ & $31.8 \pm 9.1$ & $31.8 \pm 10.1$ \\
\hline Defoliation index (\% individual) & $14.0 \pm 2.3$ & $12.4 \pm 1.4$ & $21.6 \pm 5.7$ & $27.3 \pm 9.7$ & $17.5 \pm 1.5$ & $17.1 \pm 4.7$ \\
\hline Bark damage index (\% individual) & 0.0 & 0.0 & $11.7 \pm 1.9$ & $7.1 \pm 2.9$ & 0.0 & $0.1 \pm 0.04$ \\
\hline trees $\left(\mathrm{n} \mathrm{ha}^{-1}\right)$ & 0.0 & 0.0 & $127.3 \pm 41.3$ & 0.0 & $15.9 \pm 5.7$ & 0.0 \\
\hline
\end{tabular}


Fig. 5 - Mean number of shoots per stool, basal area, regeneration (sapling) density, defoliation index, bark damage index, and percentage of dead trees for coppice-cut and control plots. Bars represent the standard error. $\left(^{*}\right): p<0.05 ;(* *): p<0.01$.

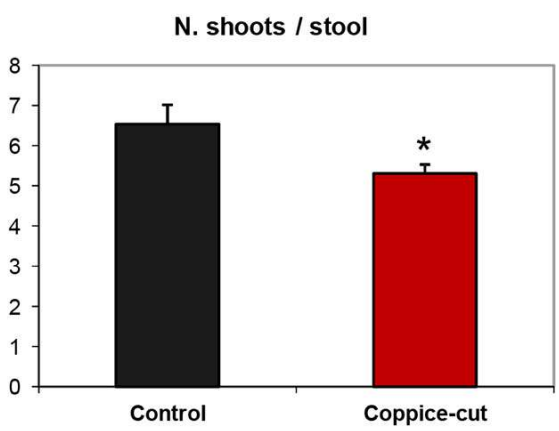

Regeneration (saplings)

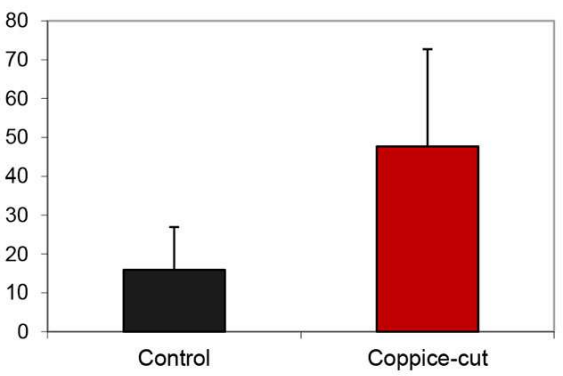

Bark damage Index (\%)

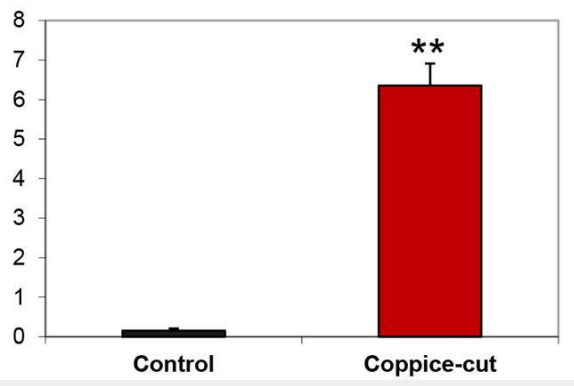

Basal area (m2/ha)

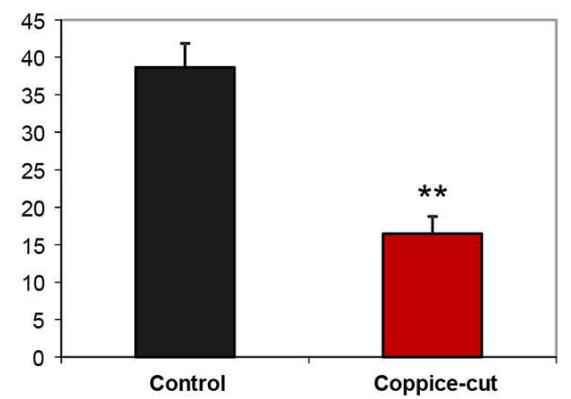

Defoliation Index (\%)

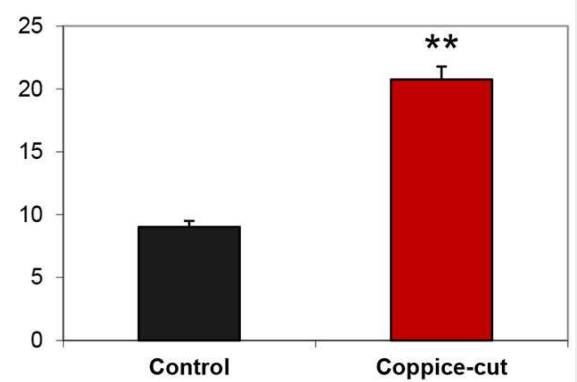

Dead trees (\%)

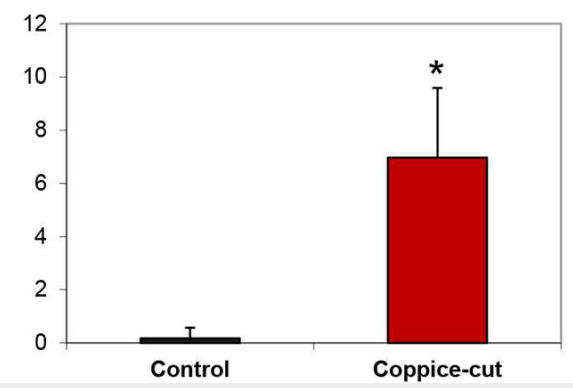

\section{Health status and dead plants}

Generally, crown defoliation was greatest in the upper and outside portions of the crown; less defoliation was observed in the lower and inside portions. By contrast, the greatest bark damage was observed in the lower part of each stem, mainly on the southern warmer exposures, and in plants bordering clearings and open areas.

Comparisons of coppice-cut and control plots revealed statistically significant differences in all the indicators of beech health (defoliation, bark damage, dead tree). The canopy defoliation index was twice as high in coppice-cut plots compared with controls $(20.77 \% \pm 1.02$ vs. $9.03 \% \pm 0.48$ - Stu- dent's $t=10.51 ; p<0.01 ; d f=472-$ Fig. 5$)$. The bark damage index, which was negligible in control plots $(0.15 \% \pm 0.06)$, was relatively high in the cut stands $(6.35 \% \pm 0.56-$ Student's $t=12.24 ; p<0.01 ; d f=472)$. As a consequence, a possible drought effect could be excluded. Moreover, the percentage of dead trees within sample plots was

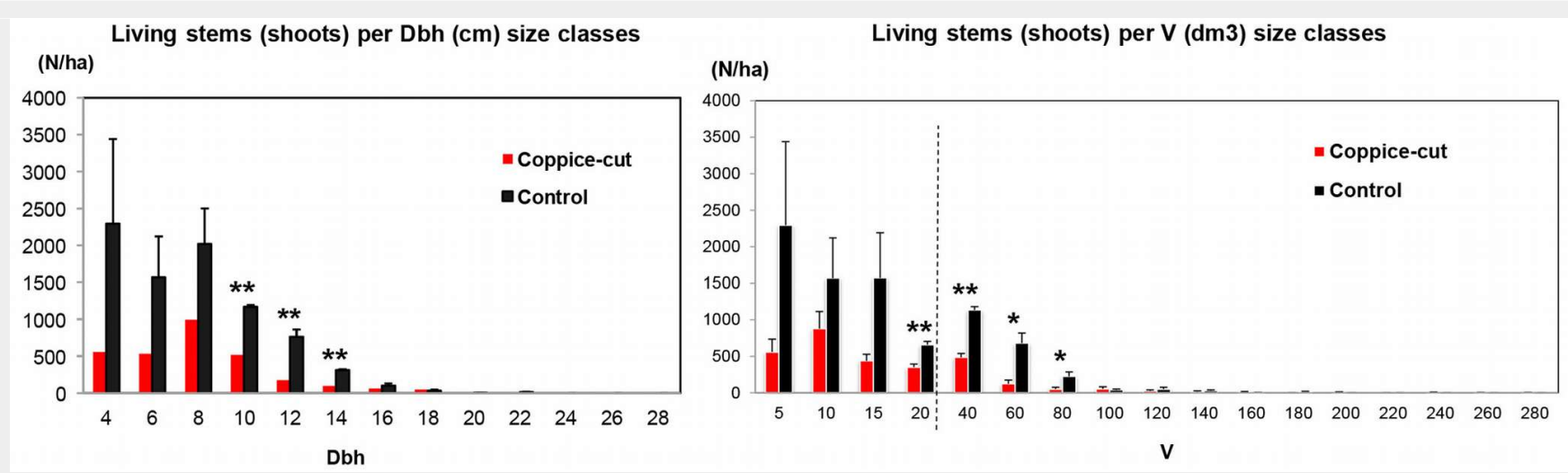

Fig. 6 - (a) Diameter distribution of living stems (shoots) per hectare in the coppice-cut and control plots. (b) Distribution of cumulative volume per individual, obtained as the sum of all shoots for each individual. Seedlings and saplings were not included. Bars re present the standard error. $(*): p<0.05 ;(* *): p<0.01$. 
(a) Regeneration (N/ha)

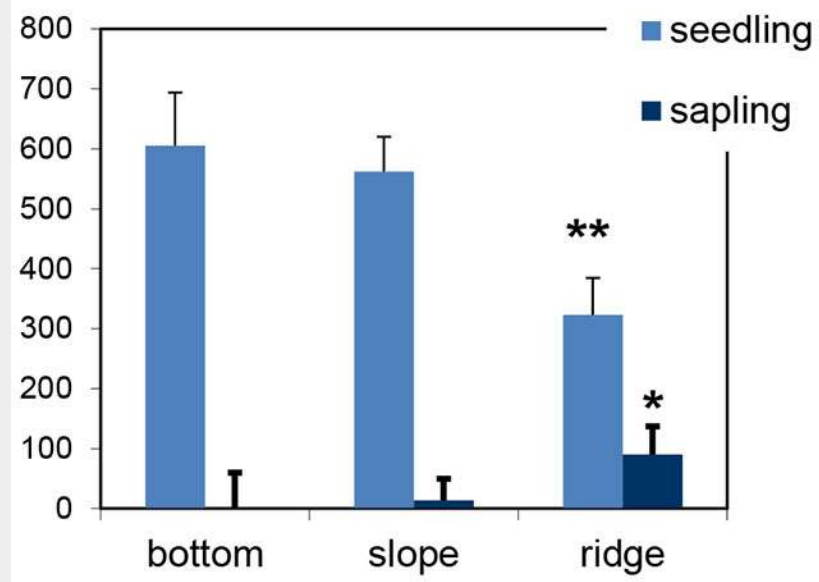

(b) Regeneration (N/ha) (only coppice-cut plots)

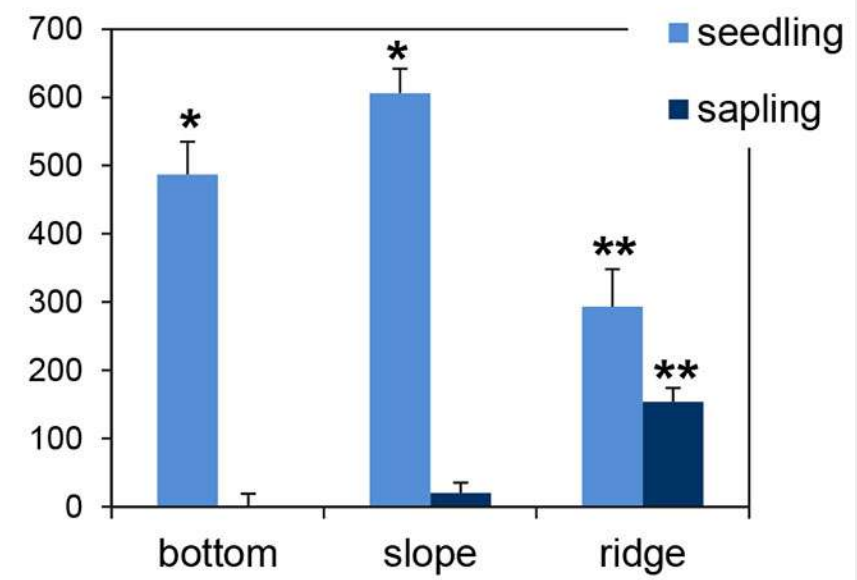

Fig. 7 - Mean and standard error of beech regeneration, distinguished as seedling and sapling, by topographic position of the plot analyzed. (a) All plots; (b) coppice-cut plots. (*): $p<0.05 ;(* *): p<0.01$.

(a) Defoliation Index (\%)

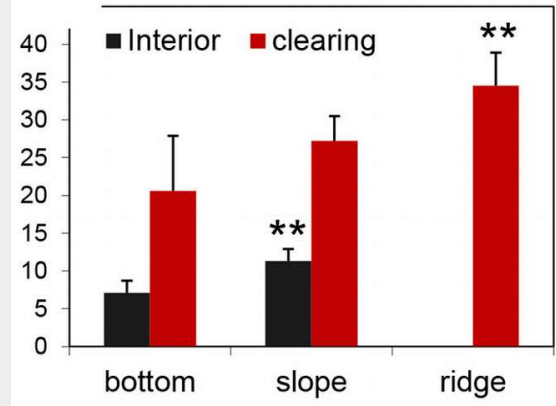

(b) Defoliation Index (\%)

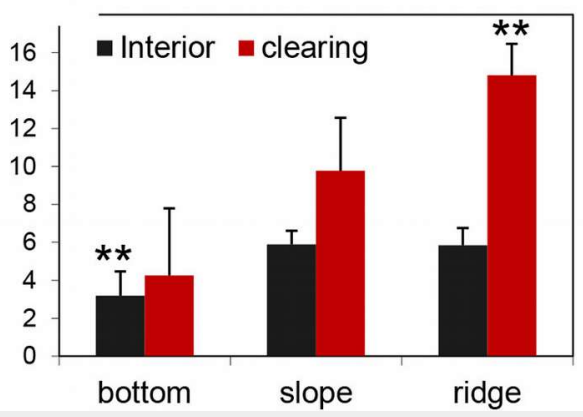

(c) Bark damage Index (\%)

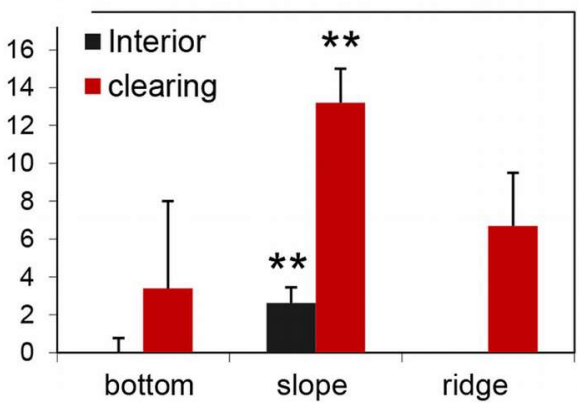

Fig. 8 - Mean and standard error of health status indicators by topographic position of the plot analyzed. (a) Defoliation index of coppice-cut plots; (b) defoliation index of control plots; (c) bark damage index of coppice-cut plots. Significant differences among topographic positions after Tukey's post-hoc test are indicated (**: $p<0.01)$.

also higher in coppice-cut $(6.97 \% \pm 2.62)$ as compared with control areas $(0.17 \% \pm 0.41-$ Student's $t=-2.49 ; \mathrm{p}<0.05 ; \mathrm{df}=10-$ Fig. 5$)$. The analysis of the health status of trees with respect to the topographic gradient revealed that the defoliation index and bark damage index were higher on ridges and slopes than on bottom sites. Additionally, trees bordering clearings were less healthy than trees in stand interiors (Fig. 8). Indeed, beech trees in coppice-cut plots located on ridges and in clearings showed the highest defoliation index (up to $34.5 \% \pm$ 4.4 - the highest value was in plot $D$ with $41 \%$ defoliation), which was significantly higher than those found for in slope and bottom positions (Tukey's post-hoc test, $p$ $<0.01$ - Fig. 8a). Beech trees in control plots with the same topographic position and canopy cover showed similar results, although with lower values, e.g., the defoliation index was $14.8 \% \pm 1.6$ for trees in the clearings on ridges (Fig. 8b).

The bark damage index is reported only for coppice-cut plots (Fig. 8c); in control plots, the index was close to $0 \%$. The bark damage index was significant higher in plots on slopes for both edge and interior trees (Tukey's post-hoc test, $\mathrm{p}<0.01$ - Fig. $8 c)$.

In coppice-cut plots, dead beech trees were significantly more abundant on slopes and ridges (Tab. 3).

\section{Discussion and conclusions}

Southern European beech forests mainly grow in the mountain-Mediterranean vegetation belt of northeastern Spain, southern Italy and Sicily, and central Greece (Piovesan et al. 2005, Peñuelas et al. 2007, Tsiripidis et al. 2007). Beech in Sicily grow at the very edge of the species' European range (Cullotta et al. 2013). Beech stands on the Madonie mountains (about 2500 ha), as well as those located on the eastern slopes of Mount Etna (about 2000 ha), are highly fragmented as compared with the wider beech forests of the Nebrodi mountains (approximately 10000 ha - Fig. 1b). Moreover, the latter stands are characterized by higher biomass and more growing stock as a result of deeper soils and more humid environment (Hofmann et al. 2011), while the former stands grow on lessdeveloped shallow soils, and are mainly composed of multi-stemmed trees (several shoots on each stool), due to both environmental conditions and past coppicing.

Our results confirm that vegetative regeneration (sprouting) largely predominates in high mountains and in topographically marginal sites, which is a common reproductive strategy for beech growing under unfavorable environmental conditions (Peters 1997), especially in the Mediterranean region (Peñuelas et al. 2007, Papalexandris \& Milios 2010, Bianchi et al. 2011, Cullotta et al. 2013).

Past silvicultural practices carried out in the analyzed stands have fostered irregular stand structures and increased structural variability, reinforcing the importance of the adoption of a correct coppicing management (Ciancio et al. 2006, 2008, Coppini \& Hermanin 2007, Nocentini 2009). Coppice with standards was the most common treatment of beech stands in Sicily, including the Madonie mountains, until the first half of the last century (Hofmann 1960). Their subsequent abandonment or the irregular (less frequent) utilization have contributed to the current atypical stand structures and dynamics.

Our results revealed a significant impact 
of silvicultural practices on the studied beech forests. Felling practices carried out in the last two decades (Tab. 2), uniformly applied to a coppice-like stand structure without consideration of site-specific environmental conditions (i.e., topography and soil), negatively influenced stand development. Ciancio \& Nocentini (2004) emphasized that coppicing in harsh climates and environmental conditions produces many crooked and branched stems.

The comparison of coppice-cut and control plots indicated a high utilization rate, i.e., $20-40 \%$ of plant basal area (G) and volume (V) and up to $66 \%$ of stem (shoots) density (Tab. 2). The higher $G$ and $V$ observed in the control plots as compared with coppice-cut plots (Tab. 3 ) reflect the different architecture of individual trees in the two stand types, because stools in control plots tend to have more stems (shoots) per individual than stools in coppiced plots (Fig. 5, Fig. 6).

The analysis of regeneration did not reveal significant effects of the silvicultural treatment on seedlings and saplings density. However, seedlings tend to be less abundant in coppice-cut plots compared with controls, while the opposite was true for saplings.

Climate, topography, soil and stand structure are the main factors controlling seedling density at the microsite level (Silva et al. 2012). In this study, we found a considerably lower number of seedlings in plots located on ridges and mountaintops as compared with those in the bottomlands, with the largest reduction of recruitments in the coppice-cut plots (Fig. 7). On the other hand, such reduction was not found for saplings. Similar results were reported by Barbeta et al. (2011), who compared fragmented and continuous forests at the edge of the species' range in southeastern Spain. However, the projected increasing temperatures in the Mediterranean region are likely to reduce the frequency of successful seedling establishment (Jump et al. 2007, Pulido et al. 2008, Wagner et al. 2010), possibly leading to a general decline and local extinction (Piovesan et al. 2008).

The observed decrease in seedling establishment and plant health are indicative of the poor site quality at the coppice-cut stands analyzed. Our results suggest a strong effect of silvicultural treatment on habitat quality: beech trees in coppiced plots were more than twice as defoliated and had 6 times more bark damage than those in control plots. Moreover, dead trees were 7 times more abundant in coppice-cut than in control plots (Fig. 5).

The defoliation index, the bark damage index, and the percentage of dead trees were strongly correlated with local topography (Fig. 8, Tab. 3). The defoliation index of coppiced plots on ridges was nearly double ( $35 \%$ mean defoliation) that that of coppiced plots in bottomlands $(21 \%$ Fig. 8a). The effect of topography was also evident in the control plots, with approxi- mately 3-4 times more damage on ridges than in bottomlands. Similar results were also observed for other indicators of tree health, such as bark damage and frequency of dead trees. These findings support the hypothesis that the negative effect of inappropriate silvicultural practices could be strengthened by the worse environmental conditions expected under the current climate change.

In summary, our results suggest that the health of beech stands on the Madonie mountains declines in more marginal sites, at higher altitudes, and on steep slopes, ridges and summit plateaus, as a consequence of the combined effect of anthropogenic and ecological factors. In particular, the shallow soils (siliceous, rocky and skeletal) and the effects of strong winds, such as increased evapotranspiration and air turbulence (Harper et al. 2005) are among the most limiting environmental factors. Aridity and wind speeds are expected to be higher in these marginal sites, affecting tree health through drought and mechanical damage (Barbeta et al. 2011).

In addition, habitat quality in the studied sites is strongly affected by the lack of a continuous canopy cover (Heithecker \& Hapern 2007). The negative effects of habitat fragmentation on tree health have been attributed to edge and area effects (Ferreira \& Laurance 1997, Harper et al. 2005). The effect of direct sun on trees bordering clearings is particularly evident in their health indicators (defoliation, bark damage, dead trees), especially for Mediterranean beech stands at high altitudes or at the southernmost edge of the species' range.

Environmental stress can be strongly enhanced by the adoption of different management regimes or silvicultural practices (Kramer \& Kozlowski 1979, Ciancio et al. 2006, Wagner et al. 2010). Extensive coppicing in the analyzed plots $A, C$ and $D$ increased environmental stress. Coppicing amplified the ecological effects of forest fragmentation and canopy gap formation, affecting growth patterns, regeneration processes, and sunlight effects ( Topoliantz \& Ponge 2000, Collet et al. 2001, Caquet et al. 2009, Robson et al. 2009).

To mitigate the negative effects of frequent coppice clearcutting on soils, landscape and biodiversity conservation, the conversion of coppices to high forests or to natural stand dynamics with continuous cover has recently become an increasingly common management goal, especially in hilly and mountainous Mediterranean regions (Serrada et al. 1998, Ciancio et al. 2006, Nocentini 2009, Montagnoli et al. 2012). Anyway, in harsh habitats (as in the case study) where multi-stemmed shrublike growth forms are common and conversion is not feasible, it is compulsory to maintain a high canopy cover and a large stem density. Therefore, management in such ecological context should aim at reducing the fragmentation of beech stands and increasing canopy cover by plantation. In summary, the results of this study highlight the various ecological and management effects that influence habitat quality in outlying beech stands of the Madonie mountains. Here, beech has to be considered as a "pioneer" species surviving in extreme habitats, characterized by severe summer drought, shallow soils, strong winds, scattered canopy cover and unsuitable management practices, such as occasional wood harvesting and uncontrolled grazing. In this context, traditional silvicultural practices used in the past are no longer suitable and quite detrimental to the stands' survival. A cautious management approach should be adopted, avoiding felling practices and other anthropogenic disturbances in the most marginal topographic sites such as ridges, summit plateaus and steep slopes.

\section{References}

Aertsen W, Janssen E, Kint V, Bontemps JD, Van Orshoven J, Muys B (2014). Long-term growth changes of common beech (Fagus sylvatica L.) are less pronounced on highly productive sites. Forest Ecology and Management 312: 252-259. doi: 10.1016/j.foreco.2013.09.034

Attorre F, Francesconi F, Scarnati L, De Sanctis $M$, Alfò $M$, Bruno $F$ (2008). Predicting the effect of climate change on tree species abundance and distribution at a regional scale. iForest 1: 132-139. - doi: 10.3832/iforo467-0010132

Barbati A, Corona P, Marchetti M (2006). European forest types: categories and types for sustainable forest management reporting and policy. EEA Technical Report, Copenhaghen, Denmark, pp. 111. [online] URL: http://iris.unimol. it/handle/11695/19445?mode=full.14

Barbeta A, Peñuelas J, Ogaya R, Jump AS (2011). Reduced tree health and seedling production in fragmented Fagus sylvatica forest patches in the Montseny Mountains (NE Spain). Forest Ecology and Management 261: 2029-2037. - doi: 10.1016/j.foreco.2011.02.029

Benito Garzon M, Sanchez De Dios R, Sainz Ollero $H$ (2008). Effects of climate change on the distribution of Iberian tree species. Applied Vegetation Science 11: 169-178. - doi: 10.3170/20087-18348

Bengtsson J, Nilsson SG, Franc A, Menozzi P (2000). Biodiversity, disturbances, ecosystem function and management of European forest. Forest Ecology and Management 132: 39-50. doi: 10.1016/S0378-1127(00)00378-9

Bergmeier E, Dimopoulos P (2001). Fagus sylvatica forest vegetation in Greece: syntaxonomy and gradient analysis. Journal Vegetation Science 12: 109-126. - doi: 10.2307/3236679

Berry PM, Dawson TP, Harrison PA, Pearson RG (2002). Modelling potential impacts of climate change on the bioclimatic envelope of species in Britain and Ireland. Global Ecology and Biogeography 11: 453-462. - doi: 10.1111/j.1466-8238. 2002.00304.x

Bianchi L, Bottacci A, Calamini G, Maltoni A, Mariotti B, Quilghini G, Salbitano F, Tani A, Zoccola A, Paci M (2011). Structure and dynamics of a beech forest in a fully protected area in the northern Apennines (Sasso Fratino, Italy). iFor- 
est 4: 136-144. - doi: 10.3832/iforo564-004

Borghetti M, Giannini R (2004). Natural regeneration in woodland management. In: "Biodiversity Conservation and Habitat Management" (Gherardi F, Corti C, Gualtieri M eds). Encyclopedia of Life Support Systems (EOLSS), UNESCO, Eolss Publishers, Oxford, UK, pp. 11.

Brullo S, Guarino R, Minissale P, Siracusa G, Spampinato $G$ (1999). Syntaxonomical analysis of the beech forests from Sicily. Annali di Botanica (Roma) 57: 121-132. [in Italian] [online] URL: http://laboratoriocritico.uniroma1.it/index.php/ Annalidibotanica/article/view/9052

Camerano P, Cullotta S, Varese P (2011). Strumenti conoscitivi per la gestione delle risorse forestali della Sicilia. Tipi Forestali [Information tools for the management of forest resources of Sicily. Forest Types]. Regione Siciliana, Litograf Editor S.R.L., Città di Castello, Perugia, Italia, pp. 192. [in Italian]

Caquet B, Montpied P, Dreyer E, Epron D, Collet $C$ (2009). Response to canopy opening does not act as a filter to Fagus sylvatica and Acer sp. Advance regeneration in a mixed temperate forest. Annals of Forest Science 67: 105-116. - doi: $10.1051 /$ forest/2009086

Ciancio O, Nocentini S (2004). The coppice forest. Silviculture, regulation, management. In: "Il bosco ceduo. Selvicoltura, assestamento, gestione" (Ciancio O, Nocentini S eds). Accademia Italiana di Scienze Forestali, Firenze, Italy, pp. 679-701. [in Italian]

Ciancio O, Corona P, Lamonaca A, Portoghesi L, Travaglini D (2006). Conversion of clearcut beech coppices into high forests with continuous cover: a case study in central Italy. Forest Ecology and Management 224: 235-240. - doi: 10.1016/j.foreco.2005.12.045

Ciancio O, lovino F, Menguzzato G, Nicolaci A (2008). Struttura e trattamento in alcune faggete dell'Appennino meridionale [Structure and silvicultural management of some beech stands in the Southern Apennines]. Italian Journal of Forest and Mountain Environments 63: 465-481. [in Italian] - doi: 10.4129/IFM.2008.6.01 Ciais P, Reichstein M, Viovy N, Granier A, Ogee J, Allard V, Aubinet M, Buchmann N, Bernhofer C, Carrara A, Chevallier F, De Noblet N, Friend AD, Friedlingstein $P$, Grunwald $T$, Heinesch B, Keronen P, Knohl A, Krinner G, Loustau D, Manca G, Matteucci G, Miglietta F, Ourcival JM, Papale D, Pilegaard K, Rambal S, Seufert G, Soussana JF, Sanz MJ, Schulze ED, Vesala T, Valentini R (2005). Europe-wide reduction in primary productivity caused by the heat and drought in 2003. Nature 437: 529-533. - doi: 10.1038/natu reo3972

Collet C, Lanter O, Pardos M (2001). Effects of canopy opening on height and diameter growth in naturally regenerated beech seedlings. Annals of Forest Science 58: 127-134. - doi: 10.1051/forest:2001112

Coppini M, Hermanin L (2007). Restoration of selective beech coppices: a case study in the Apennines (Italy). Forest Ecology and Management 249: 18-27. - doi: 10.1016/j.foreco.2007. 04.035

Cullotta S, Marchetti M (2007). Forest types for biodiversity assessment at regional level: the case study of Sicily (Italy). European Journal of Forest Research 126: 431-447. - doi: 10.1007/s103 42-006-0166-y

Cullotta S, Puzzolo V, Fresta A (2013). The southernmost beech (Fagus sylvatica) forests of Europe (Mount Etna, Italy): ecology, structural stand-type diversity and management implications. Plant Biosystems 149 (1): 88-99. - doi: 10.1080/11263504.2013.814603

Dittmar C, Fricke W, Elling W (2006). Impact of late frost events on radial growth of common beech (Fagus sylvatica L.) in southern Germany. European Journal of Forest Research 125: 249259. - doi: 10.1007/s10342-005-0098-y

Erasmus BFN, De Squeira MF, Grainiger A, Hannah L, Hughes L, Huntely B, Van Jaarsfeld AS, Midgley GF, Miles L, Ortega Huerta MA, Peterson AT, Phillips OL, Williams SE (2004). Extinction risk from climate change. Nature 427: $145-$ 148. - doi: 10.1038/nature02121

Ferreira LV, Laurance WF (1997). Effects of forest fragmentation on mortality and damage of selected trees in Central Amazonia. Conservation Biology 11 (3): 797-801. - doi: 10.1046/j.15231739.1997.96167.x

Gentile S (1969). Sui faggeti dell'Italia meridionale [Note on the beech woodlands of Southern Apennines]. Atti Istituto Botanico, Università Pavia 5: 207-306. [in Italian]

Gessler A, Keitel C, Kreutzwleser J, Matyssek R, Seller W, Rennenberg H (2007). Potential risk for European beech (Fagus sylvatica L.) in a changing climate. Trees 21: 1-11. - doi: 10.1007/ soo468-006-0107-x

Granier A, Reichstein $M$, Bréda N, Janssens IA, Falge $E$, Ciais $P$, Grünwald $T$, Aubinet $M$, Berbigier $\mathrm{P}$, Bernhofer $\mathrm{C}$, Buchmann $\mathrm{N}$, Facini $\mathrm{O}$, Grassi $G$, Heinesch $B$, Ilvesniemi $H$, Keronen $P$, Knohl A, Köstner B, Lagergren F, Lindroth A, Longdoz B, Loustau D, Mateus J, Montagnani L, Nys C, Moors E, Papale D, Peiffer M, Pilegaard K, Pita G, Pumpanen J, Rambal S, Rebmann C, Rodrigues A, Seufert G, Tenhunen J, Vesala T, Wang Q (2007). Evidence for soil water control on carbon and water dynamics in European forests during the extremely dry year: 2003. Agriculture and Forest Meteorology 143: 123-145. - doi: 10.1016/j.agrformet.2006.12.0 04

Harper KA, Macdonald SE, Burton PJ, Chen JQ, Brosofske KD, Saunders SC, Euskirchen ES, Roberts D, Jaiteh MS, Esseen PA (2005). Edge influence on forest structure and composition in fragmented landscapes. Conservation Biology 19: 768-782. - doi: 10.1111/j.1523-1739.2005.000 45. $x$

Heithecker TD, Halpern CB (2007). Edge-related gradients in microclimate in forest aggregates following structural retention harvests in eastern Washington. Forest Ecology and Management 287: 163-173. - doi: 10.1016/j.foreco.2007.0 5.003

Hofmann A (1960). Il faggio in sicilia [The beech in Sicily]. Flora et Vegetatio Italica, mem. 2. Gianasso Editore, Sondrio, Italy, pp. 235. [in Italian]

Hofmann A, Cibella R, Bertani R, Miozzo M, Fantoni I, Luppi S (2011). Strumenti conoscitivi per la gestione delle risorse forestali della Sicilia. Sistema informativo forestale [Information tools for the management of forest resources of Sicily. Forest information system]. Regione Siciliana, Litograf Editor, Città di Castello, Peru- gia, Italy, pp. 208. [in Italian]

INFC (2005). Inventario Nazionale delle Foreste e dei Serbatoi Forestali di Carbonio. Secondo inventario forestale nazionale italiano. Metodi e risultati. [The national inventory of forests and carbon stocks INFC 2005. Second Italian Forest Inventory. Methods and results]. Ministero Politiche Agricole Alimentari Forestali, Edagricole - II Sole 24 ore, Bologna, Italy, pp. 653. [in Italian]

Jump AS, Hunt JM, Peñuelas J (2006). Rapid climate change-related growth decline at the southern range edge of Fagus sylvatica. Global Change Biology 12: 2163-2174. - doi: 10.1111/j.13 65-2486.2006.01250.x

Jump S, Hunt JM, Penuelas J (2007). Climate relationships of growth and establishment across the altitudinal range of Fagus sylvatica in the Montseny mountains, northeast Spain. Ecoscience 14: 507-518. - doi: 10.2980/1195-6860(2007) 14[507:CROGAE]2.0.CO;2

Kramer PJ, Kozlowski TT (1979). Physiology of woody plants. Academic Press, New York, USA, pp. 811.

Kramer K, Degen B, Buschbom J, Hickler T, Thuiller W, Sykes MT, De Winter W (2010). Modelling exploring of the future of European beech (Fagus sylvatica L.) under climate change - range, abundance, genetic diversity and adaptive response. Forest Ecology and Management 259: 2213-2222. - doi: 10.1016/j.foreco.2009.12. 023

Lombardi F, Klopic M, Di Martino P, Tognetti R, Chirici G, Boncina A, Marchetti M (2012). Comparison of forest stand structure and management of silver fir-European beech forests in the Central Apennines, Italy and in the Dinaric Mountains, Slovenia. Plant Biosystems 146: 114123. - doi: 10.1080/11263504.2011.623190

MAF-ISAFA (1985). Inventario Forestale Nazionale 1985 . Sintesi metodologica e risultati. [National Forest Inventory 1985. Synthesis of methodology and results]. Ministero Agricoltura e Foreste, Istituto Sperimentale per l'Assestamento Forestale e I'Alpicoltura, Trento, Italy, pp.464. [in Italian]

Magri D, Vendramin GG, Comps B, Dupanloup I, Geburek T, Gomory D, Latalowa M, Litt T, Paule L, Roure JM, Tantau I, Van Der Knaap WO, Petit RJ, De Beaulieu JL (2006). A new scenario for the quaternary history of European beech populations: palaeobotanical evidence and genetic consequences. New Phytologist 171: 199-221. - doi: 10.1111/j.1469-8137.2006.01740.x

Montagnoli A, Terzaghi M, Di lorio A, Scippa GS, Chiatante D (2012). Fine-root seasonal pattern, production and turnover rate of European beech (Fagus sylvatica L.) stands in Italy Prealps: possible implications of coppice conversion to high forest. Plant Biosystems 146: 10121022. - doi: 10.1080/11263504.2012.741626

Nahm M, Matzarakis A, Rennenberg H, Gessler A (2007). Seasonal courses of key parameters of nitrogen, carbon and water balance in European beech (Fagus sylvatica L.) grown of four different study sites along a European NorthSouth climate gradient during the 2003 drought. Trees 21: 79-92. - doi: 10.1007/s00468006-0098-7

Nocentini S (2009). Structure and management of beech (Fagus sylvatica L.) forests in Italy. 
iForest 2: 105-113. - doi: 10.3832/iforo499-002 Papalexandris C, Milios E (2010). Analysis of natural Fagus sylvatica L. s.l. regeneration in low elevation stands located in the central part of the Evros region in the northeastern Greece: is sprout origin regeneration significant for species maintenance? Plant Biosystems 144: 784792. - doi: 10.1080/11263504.2010.513867

Peñuelas J, Boada M (2003). A global changeinduced biome shift in the Montseny mountains (NE Spain). Global Change Biology 9: 131140. - doi: 10.1046/j.1365-2486.2003.00566.x Peñuelas J, Ogaya R, Boada M, Jump AS (2007). Migration, invasion and decline: changes in recruitment and forest structure in a warminglinked shift of European beech forest in Catalonia (NE Spain). Ecography 30: 830-838. - doi: 10.1111/j.2007.0906-7590.05247.x

Peters R (1997). Beech forests: woody species composition, populations and spatial aspects. Geobotany, Vol. 24, Kluwer Academic Publishers, Dordrecht, The Netherlands, pp. 187. - doi: 10.1007/978-94-015-8794-5_6

Pignatti G (2011). Forest vegetation in view of some scenarios of climate change in Italy. Forest@ 8 (1): 1-12. [in Italian with English summary] - doi: 10.3832/eforo650-008

Piovesan G, Biondi F, Bernabei M, Di Filippo A, Schirone B (2005). Spatial and altitudinal bioclimatic zones of the Italian peninsula identified from a beech (Fagus sylvatica L.) tree-ring network. Acta Oecologica 27: 197-210. - doi: 10.10 16/j.actao.2005.01.001

Piovesan G, Biondi F, Di Filippo A, Alessandrini A, Maugeri $M$ (2008). Drought-driven growth reduction in old beech (Fagus sylvatica L.) forests of the central Apennines, Italy. Global Change Biology 14: 1265-1281. - doi: 10.1111/j.1365-2486. 2008.01570.x

Pulido F, Valladeres F, Calleja JA, Moreno G, González-Bornay G (2008). Tertiary relict trees in a Mediterranean climate: abiotic constraints on the persistence of Prunus lusitanica at the eroding edge of its range. Journal of Biogeography 35: 1425-1435. - doi: 10.1111/j.1365-2699. 2008.01898.x

Raimondo FM, Gianguzzi L, Schicchi R (1992). Carta della vegetazione del massiccio carbonatico delle Madonie (Sicilia centro-settentrionale) [Vegetation map of the limestone massif of the Madonie Mts. (CN-Sicily)]. Quaderni Botanica Ambientale Applicata 3: 23-40. [in Italian]

Rennenberg $\mathrm{H}$, Loreto F, Polle A, Brilli F, Fares S, Beniwal RS, Gessler A (2006). Physiological responses of forest trees to heat and drought. Plant Biology 8: 556-571. - doi: 10.1055/s-2006924084

Robson TM, Rodríguez-Calcerrada J, SánchezGómez DG, Aranda I (2009). Summer drought impedes beech seedling performance more in a sub-Mediterranean forest understory than in small gaps. Tree Physiology 29: 249-259. - doi: 10.1093/treephys/tpno23

Rose L, Leuschner C, Köckemann B, Buschmann $H$ (2009). Are marginal beech (Fagus sylvatica L.) provenances a source for drought tolerant ecotypes? European Journal of Forest Research 128: 335-343. - doi: 10.1007/s10342-009-0268-4 Sabatini F, Burrascano S, Lombardi F, Chirici G, Blasi C (2015). An index of structural complexity for Apennine beech forests. iForest 8 (3): 314323. - doi: 10.3832/ifor1160-008

Serrada R, Bravo A, Sànchez I, Allué M, Elena R, San Miguel A (1998). Conversion into high forest in coppices of Quercus ilex subs. ballota L. in the Central region of Iberian Peninsula. Annali Istituto Sperimentale per la Selvicoltura 27: 149160.

Silva DE, Rezende Mazzella P, Legay M, Corcket E, Dupouey JL (2012). Does natural regeneration determine the limit of European beech distribution under climatic stress? Forest Ecology and Management 266: 263-272. - doi: 10.1016/j. foreco.2011.11.031

Seynave I, Gegout JC, Herve JC, Dhote JF (2008). Is the spatial distribution of European beech (Fagus sylvatica L.) limited by its potential height growth? Journal of Biogeography 35: 1851-1862. - doi: 10.1111/j.1365-2699.2008.01930.x Thomas CD, Cameron A, Green RE, Bakkenes M, Beaumont $L$, Collingham $Y C$, Erasmus BFN, Ferriera De Siqueira M, Grainger A, Hannah L, Hughes L, Huntley B, Van Jaarsveld AS, Midgley GF, Miles L, Ortega-Huerta MA, Peterson AT, Phillips OL, Williams SE (2004). Extinction risk from climate change. Nature 427: 145-148. - doi: 10.1038/nature02121

Topoliantz S, Ponge JF (2000). Influence of site conditions on the survival of Fagus sylvatica seedlings in an old-growth beech forest. Journal of Vegetation Science 11: 369-374. - doi: $10.2307 / 3236629$

Tsiripidis I, Bergmeier E, Dimopoulos P (2007). Geographical and ecological differentiation in Greek Fagus forest vegetation. Journal of Vegetation Science 18: 743-750. - doi: 10.1111/j.16541103.2007.tb02589.x

Wagner S, Collet C, Madsend P, Nakashizukae T, Nyland RD, Sagheb-Talebig K (2010). Beech regeneration research: from ecological to silvicultural aspects. Forest Ecology and Management 259: 2172-2182. - doi: 10.1016/j.foreco.2010.02. 029 